\title{
KARATERISTIK SIFAT FISIKA BAMBU TALI (GIGANTOLOCHLOA APUS KURZ), SEBAGAI BAHAN BAKU BAMBU KERAJINAN
}

\author{
Physical Properties of Tali Bamboo (Gigantolochloa Apus Kurz.) As Raw Materials for \\ Bamboo Crafts
}

Febriana Tri Wulandari

Jurusan Kehutanan, Fakultas Pertanian, Universitas Mataram

Jalan Majapahit No 62, Mataram, NTB

Email : aritri71@yahoo.com

Direvisi : 16/01/2020, Diterbitkan 02/03/2020

\begin{abstract}
The centre of bamboo crafts in Gunung Sari District is the largest bamboo centre in West Lombok Regency. One of the bamboo species which is usually used as raw materials is tali bamboo. Studies of physical properties of this bamboo have not been carried out resulting poor quality of bamboo crafts. The physical property was essensial information which would be used for enhancing the products because it correlated with dimensional stability of the bamboo. The objectives of this study were to identify the physical properties of the bamboo with reference to the axial direction. The experiment design was complete random design employing the axial directions (bottom, middle, and top portions) as treatments. The statistical analyses were Anova with range tests at $\alpha=5 \%$. The results showed that the physical properties were: fresh moisture content 51-119.82\%; air-dried moisture content 13.03-15.04\%; fresh volume density $0.51-0.72$; air-dried volume density $0.62-0.75$; oven volume density $0.63-0.78$. Axial directions of the physical properties were not significantly different except for the fresh moisture content. Therefore all portions of tali bamboo (bottom, middle, and top portions) could be utilized as raw materials for bamboo crafts.
\end{abstract}

Keywords; physical properties; tali bamboo; bamboo crafts

\section{ABSTRAK}

Pusat Kerajinan bambu di Kecamatan Gunung Sari merupakan sentra kerajinan terbesar di Kabupaten Lombok Barat. Salah satu jenis bambu yang biasa digunakan sebagai bahan baku kerajinan adalah bambu tali. Selama ini belum dilakukan penelitian mengenai sifat fisika bambu tali sebagai bahan baku yang digunakan. Hal ini menyebabkan produksi kerajinan yang dihasilkan memiliki kualitas yang kurang baik. Sifat fisika merupakan sifat yang paling memegang peranan penting untuk dapat meningkatkan kualitas bambu yang dihasilkan, karena berhubungan kestabilan dimensi bahan baku bambu tersebut. Tujuan dari penelitian ini untuk mengetahui sifat fisika bambu tali berdasarkan arah aksial. Metode yang digunakan dalam penelitian ini mengunakan metode eksperimen dengan menggunakan 
Rancangan Acak Lengkap (RAL) dimana perlakuan yang digunakan arah aksial bambu (pangkal, tengah dan ujung). Ukuran contoh uji mengikuti Indian Standar (IS) 6874 (2008). Analisis data yang digunakan menggunakan analisis sidik ragam Anova pada taraf $5 \%$. Hasil penelitian menunjukan nilai fisika bambu tali adalah sebagai berikut : kadar air kayu segar (51\% -119.82\%), kadar kering udara (13.03\% -15.04\%), berat jenis volume segar (0.51 $0.72)$, berat jenis volume kering udara $(0.62-0.75)$, berat jenis volume kering tanur $(0.63$ 0.78). Arah aksial tidak berpengaruh terhadap sifat fisika bambu tali kecuali pada pengujian kadar air segar, sehingga semua bagian dari batang bambu tali (pangkal, tengah dan ujung) dapat dimanfaatkan sebagai bahan baku bambu kerajinan.

Kata kunci; sifat fisika; bambu tali; bambu kerajinan

\section{PENDAHULUAN}

Potensi tanaman bambu di Indonesia cukup besar, baik dari segi jenis maupun jumlahnya. Menurut Abdullah (2014) Indonesia merupakan negara dengan produksi bambu terbesar kedua setelah cina dengan jumlah yg telah ditemukan sebanyak 154 jenis dari 1.250 sampai 1.500 jumlah bambu di dunia. Di indonesia bambu dapat ditemukan baik didataran rendah maupun pegunungan dengan ketinggian sekitar 300 mdpl yang pada umumnya ditemukan ditempat-tempat terbuka dan di daerah yang bebas dari genangan air (Praptoyo,2012). Namun menurut Eskak (2016) tanaman bambu banyak dijumpai di Indonesia pada dataran rendah hingga dengan ketinggian 750 mdpl. Bambu dapat tumbuh dengan baik di daerah yang memiliki iklim basah hingga kering.

Menurut Widjaja (2001) Lombok merupakan salah satu pulau yang memiliki persebaran bambu yang sangat banyak diantaranya bambu tali (Gigantolochloa apus Kurz), bambu Ampel (Bambusa vulgaris Schrad. ex J.C), bambu Santong (Gigantochloa atter (Hassk.) Kurz ), bambu kuning (Bambusa vulgaris var. striata), bambu petung (Dendrocalamus asper (Schult. f.) Backer ex Heyne) dan bambu Bilis (Schizostachyumlima (Blanco)Merr) (Rini et al, 2017).

Dewasa ini bambu semakin diminati oleh kalangan masyarakat karena manfaat yang sangat beragam. Namun jika kita telaah lebih jauh penggunaan bambu sudah dulu dikenalkan oleh nenek moyang kita khususnya di daerah pedesaan. Secara umum pemanfaatan bambu sangat beragam mulai dari pagar,bahan baku pembuatan mainan,maupun bahan baku industrial seperti pembuatan sumpit,aneka jenis kerajinan,kertas,bahan bangunan bahkan hingga merambah ke bidang kuliner yang diolah menjadi makanan yakni dengan memanfaatkan rebung dari bambu ( Pujirahayu,2012). Keunggulan bambu antara lain adalah keragaman jenis yang tinggi,harga relatif murah dibandingkan dengan kayu, mudah ditemukan karena bambu tersebar hampir di setiap daerah.

Kerajinan bambu di Kecamatan Gunung Sari merupakan sentra kerajinan terbesar di Kabupaten Lombok Barat. Salah satu jenis bambu yang biasa digunakan sebagai bahan baku kerajinan adalah bambu tali. Selama ini belum dilakukan penelitian mengenai sifat fisika bambu tali sebagai bahan baku di Kecamatan Gunung Sari. Sifat fisika berhubungan dengan kualitas bahan baku. Hal ini menyebabkan produksi kerajinan di kecamatan Gunung Sari yang dihasilkan memiliki kualitas yang kurang baik. Sifat fisika berhubungan dengan kemudahan dalam pengerjaan bahan baku bambu yaitu pemotongan, cacat, pengeboran, pembubutan, pengamplasan dan pengetaman (Kasmudjo et.al , 2013).. Tujuan dari penelitian ini untuk mengetahui sifat fisika bambu tali berdasarkan arah aksial dan pengaruh arah aksial terhadap sifat fisika bambu tali. 


\section{METODE}

Penelitian ini dilaksanakan pada bulan September - Desember tahun 2019. Dengan rincian sebagai berikut : pengambilan contoh uji bambu tali di kecamatan Gunung Sari Kabupaten Lombok Barat. Pengujian serta analisis data dilakukan di Laboratorium Teknologi Hasil Hutan Jurusan Kehutanan Fakultas Pertanian Universitas Mataram.

Alat dan bahan yang digunakan dalam penelitian ini adalah gergaji, pita ukur atau phiband, timbangan analitik, kaliper, oven, plastik, alat tulis, kamera, parang dan kawat strimin. Pelaksanaan peneltian meliputi pengambilan contoh uji bambu, pembagian batang bambu berdasarkan arah aksial, pengeringan udara bambu dan pengujian sifat fisika. Pengujian sifat fisika yang dilakukan adalah kadar air (\%) dan berat jenis. Contoh uji menggunakan Indian Standar (IS) 6874 (2008) untuk bagian batang bambu yaitu panjang 2,5 cm untuk pengujian kadar air dan berat jenis. Berdasarkan standar SNI 8020:2014 persyaratan bambu yang akan digunakan yaitu buluh harus lurus, kadar kering udara, bebas cacat kecuali kulit tergores dan kulit mengelupas. Sedangkan persyaratan berdasarkan penggunan sebagai bahan kerajinan dan peralatan rumah tangga ketebalan dinding $>2 \mathrm{~mm}$ untuk jenis bambu Tali, Loleb, Kuayian. Pengujian sifat fisika yang dilakukan dalam penelitian ini adalah pengujian kadar air segar, kadar kering udara, berat jenis segar, berat jenis kering udara dan berat jenis kering tanur.

Penelitian ini menggunakan Rancangan Acak Lengkap (RAL) dimana perlakuan yang digunakan adalah arah aksial yaitu: pangkal, tengah dan ujung sebanyak 3 batang. Analisis data sifat fisika menggunakan Analisis Sidik Ragam (ANOVA) pada taraf nyata $5 \%$ dan di uji lanjut dengan uji BNT (beda Nyata Terkecil) pada taraf nyata $5 \%$.

\section{HASIL dan PEMBAHASAN}

\section{Kadar Air Segar}

Kadar air bambu merupakan indikator banyaknya air dalam sepotong bambu yang dinyatakan sebagai persentase dari berat kering tanurnya. Kadar air bambu bervariasi dalam suatu batang dipengaruhi oleh umur, musim pemanenan bambu dan jenis bambu.(Syahroni, 2017). Hasil dari penelitian bambu tali memiliki nilai kadar air segar yang bervariasi. Nilai rata-rata kadar air segar dapat dilihat pada Tabel 1.

Tabel 1. Nilai kadar air segar (\%) bambu tali berdasarkan arah aksial.

Table 1. Green moisture content (\%) of tali bamboo based on the axial directions

\begin{tabular}{lllll}
\hline Arah aksial & 1 & 2 & 3 & Rata-rata \\
\hline Pangkal & 119.82 & 114.94 & 51 & 111.77 \\
\hline Tengah & 103.68 & 84.81 & 52 & 97.33 \\
\hline Ujung & 78.90 & 65.23 & 55 & 71.65 \\
\hline Rata-rata & 100.80 & 88.33 & 91.62 & 93.58 \\
\hline
\end{tabular}


Nilai kadar air segar bambu tali berkisar antara 51\% $-119.82 \%$ dengan rata-rata kadar air segar bambu sebesar 93.58\%. Kadar air tertinggi terletak pada bagian pangkal yaitu $111.77 \%$ dan kadar air terendah terletak di bagian ujung yaitu $71.65 \%$. Hal ini sesuai dengan penelitian yang dilakukan oleh Wulandari et.al (2018), yang menyatakan bahwa nilai kadar segar tertinggi terdapat pada bagian pangkal dan yang terendah pada bagian ujung.

Kadar air bambu ditentukan oleh berat air yang terkandung dalam batang. Semakin tinggi nilai kadar air yang diperoleh menunjukkan semakin banyak kandungan air pada bambu tersebut. Selain itu, kadar air juga dipengaruhi oleh umur bambu. Kadar air batang bambu yang segar berkisar 50-99\% dan pada bambu muda berkisar $80-150 \%$. Sementara pada bambu kering bervariasi antara 12-18\% (Dransfield et.al, 1995 cit Wulandari F.T ,2018 ). Dalam keadaan segar perbedaan yang lebih besar terjadi dalam satu batang yang berhubungan dengan umur, musim dan jenis. Buluh yang masih muda, berumur satu tahun memiliki kadar air yang relatif tinggi sekitar $120-130 \%$ baik pada bagian pangkal maupun ujung. Berdasarkan hasil kadar air segar yang diperoleh dalam penelitian ini dapat membuktikan bahwa bambu yang digunakan dalam penelitian merupakan jenis bambu yang berumur cukup tua karena kadar air segar berkisar antara 51\%-119.82\%. Hal ini sesuai dengan penelitian yang dilakukan Rini et.al (2017) dan Syahroni ( 2017) yang menyatakan bahwa nilai kadar air bambu dengan kisaran tersebut termasuk bambu yang cukup tua.

Tabel 2. Analisis keragaman kadar air segar bambu tali berdasarkan arah aksial Table 2. Anova of fresh moisture content of tali bamboo based on the axial directions

\begin{tabular}{llllll}
\hline Sumber Keragaman & Jumlah Kuadrat & Df & $\begin{array}{l}\text { Kuadrat } \\
\text { rata-rata }\end{array}$ & $F_{\text {hit }}$ & Sig. \\
\hline Aksial & 2477.077 & 2 & 1238.538 & 14.016 & .005 \\
Error & 530.210 & 6 & 88.368 & & \\
Total & 81827.849 & 9 & & & \\
\hline
\end{tabular}

Berdasarkan hasil analisis keragaman menunjukan bahwa pada arah aksial nilai signifikansi 0.05 , dimana nilai nilai tersebut lebih besar dari taraf yang di berikan yaitu 0,05 sehingga $\mathrm{H}_{0}$ diterima dan $\mathrm{H}_{1}$ ditolak sehingga kadar air segar pada bagian ruas bambu petung pada arah aksial seragam. Hal ini sesuai dengan pernyataan Tsoumis 1991 cit Wulandari F.T ,2018), yang menyatakan bahwa letak aksial tidak berpengaruh terhadap kadar air segar sehingga kadar air segar bambu tali tidak memiliki perbedaan yang signifikan.

\section{Kadar Air Kering Udara}

Kadar kering udara bambu tali tidak seragam. Nilai rata-rata kadar air kering udara sebesar $14,08 \%$. Nilai kadar air kering udara bambu tali dapat dilihat pada tabel dibawah ini.

Tabel 3. Nilai kadar air kering udara (\%) bambu tali berdasarkan arah aksial Table 3. Air-dried Moisture Content (\%) of tali bamboo based on the axial directions

\begin{tabular}{llccc}
\hline Arah aksial & 1 & 2 & 3 & Rata-rata \\
\hline Pangkal & 15.04 & 14.40 & 14.69 & 14.71 \\
\hline Tengah & 13.80 & 14.84 & 14.52 & 14.39 \\
\hline Ujung & 13.03 & 13.20 & 13.20 & 13.14 \\
\hline
\end{tabular}


$\begin{array}{lllll}\text { Rata-rata } & 13.96 & 14.15 & 14.14 & 14.08\end{array}$

Nilai kadar air kering udara bambu tali berkisar antara $13.03 \%-15.04 \%$. Kadar air tertinggi terletak pada bagian pangkal yaitu $14.71 \%$ dan kadar air terendah terletak di bagian ujung yaitu 13.14 \%. . Hal ini didukung dari penelitian Basri et.al (2006) hal ini disebabkan karena bagian pangkal bambu mempunyai pori-pori yang besar sehingga ketika dalam kondisi kering mampu menyerap dan mengeluarkan air lebih banyak dibandingkan bagian tengah dan ujung bambu.

Pada batang yang berumur 3-4 tahun bagian pangkal memiliki kadar air yang lebih tinggi dibandingkan bagian ujung .Kandungan air bambu lebih tinggi pada bagian dalam dibandingkan bagian luar pada arah melintang batang (Liese 1986 cit. Wulandari F.T 2018).

Tabel 4. Analisis keragaman kadar air kering udara bambu tali berdasarkan arah aksial Table 4. Anova of air-dried moisture content of tali bamboo based on the axial directions

\begin{tabular}{llllll}
\hline Sumber Keragaman & Jumlah Kuadrat & Df & $\begin{array}{l}\text { Kuadrat } \\
\text { rata-rata }\end{array}$ & $F_{\text {hit }}$ & Sig. \\
\hline Aksial & 4.105 & 2 & 2.052 & 15.546 & .004 \\
Error & .792 & 6 & .132 & & \\
Total & 1789.115 & 9 & & & \\
\hline
\end{tabular}

Berdasarkan hasil analisis keragaman menunjukan bahwa pada arah aksial nilai signifikansi 0.004 , dimana nilai nilai tersebut lebih kecil dari taraf yang di berikan yaitu 0,05 sehingga $\mathrm{H}_{0}$ ditolak dan $\mathrm{H}_{1}$ diterima sehingga kadar air kering udara pada bagian ruas bambu tali pada arah aksial berbeda. Perbedaan ini terletak pada bagian pangkal dengan bagian ujung batang namun pada bagian tengah batang tidak berbeda dengan pada bagian pangkal.

Bagian pangkal memiliki penguapan lebih cepat dari bagian ujung. Hal ini disebabkan karena pada bagian pangkal bambu mempunyai pori-pori yang besar sehingga ketika dalam kondisi kering mampu menyerap dan mengeluarkan air lebih banyak dibandingkan bagian tengah dan ujung bambu Basri et.al, 2006).

\section{Berat Jenis Segar}

Berat jenis bambu merupakan faktor yang menentukan sifat - sifat fisik dan mekanika merupakan banyak zat atau sel dinding. Bambu mempunyaiberat jenis berarti mempunyai jumlah zat dinding sel per satuan volume. Berat jenis benda padat biasanya dinyatakan sebagai perbandingan berat benda terhadap suatu volume air yang sama dengan volume benda itu. Sedangkan kerapatan suatu benda homogen adalah massa per satuan volume atau massa dibagi dengan volume (Prawirohatmodjo, 2012).

Dalam penelitian ini berat jenis diukur dalam tiga kondisi volume yaitu volume basah, volume kering udara dan volume kering tanur. Nilai berat jenis segar bambu tali dapat dilihat pada tabel 5 dibawah ini.

Tabel 5. Nilai berat jenis segar bambu tali berdasarkan arah aksial Table 5. Green specific grafity tali bamboo based on the axial directions

\begin{tabular}{ccccc}
\hline Arah aksial & 1 & 2 & 3 & Rata-rata \\
\hline Pangkal & 0.51 & 0.52 & 0.55 & 0.53
\end{tabular}




\begin{tabular}{|c|c|c|c|c|}
\hline Tengah & 0.55 & 0.62 & 0.53 & 0.57 \\
\hline Ujung & 0.62 & 0.70 & 0.72 & 0.68 \\
\hline Rata-rata & 0.56 & 0.61 & 0.60 & 0.59 \\
\hline \multicolumn{5}{|c|}{$\begin{array}{l}\text { Nilai berat jenis segar bambu tali berkisar } 0.51-0.72 \text { dengan nilai rata-rata berat jenis } \\
\text { ar } 0.59 \text {. Berat jenis tertinggi terletak pada bagian ujung yaitu } 0,68 \text { dan terendah pada } \\
\text { pangkal yaitu } 0.53 \text {. Rata-rata berat jenis cenderung meningkat dari pangkal menuju } \\
\text { Hal ini didukung oleh penelitian Wulandari } F . T(2015) \text {, yang menyatakan bambu tali } \\
\text { rung meningkat dari pangkal menuju ujung batang bambu. Hal ini disebabkan kadar air } \\
\text { bagian pangkal lebih tinggi dibandingkan dengan bagian tengah dan ujung. Kadar air } \\
\text { erat jenis memiliki hubungan berbanding terbalik, dimana bila kadar air tinggi maka berat } \\
\text { ya cenderung rendah. }\end{array}$} \\
\hline
\end{tabular}

Tabel 6. Analisis keragaman berat jenis segar bambu tali berdasarkan arah aksial

Table 6. specific grafity green bamboo based on the axial directions

\begin{tabular}{llllll}
\hline Sumber Keragaman & Jumlah Kuadrat & Df & $\begin{array}{l}\text { Kuadrat } \\
\text { rata-rata }\end{array}$ & F $_{\text {hit }}$ & Sig. \\
\hline Aksial & 0.038 & 2 & 0.019 & 10.415 & 0.011 \\
Error & 0.011 & 6 & 0.002 & & \\
Total & 3.194 & 9 & & & \\
\hline
\end{tabular}

Berdasarkan hasil analisis keragaman menunjukan bahwa pada arah aksial nilai signifikansi 0.011 , dimana nilai nilai tersebut lebih kecil dari taraf yang di berikan yaitu 0,05 sehingga $\mathrm{H}_{0}$ ditolak dan $\mathrm{H}_{1}$ diterima sehingga berat jenis segar bambu tali pada arah aksial berbeda. Perbedaan ini terletak pada bagian pangkal dan bagian tengah batang berbeda dengan bagian ujung batang namun pada bagian tengah batang tidak berbeda dengspecian pada bagian pangkal. Dengan mengetahui nilai berat jenis memudahkan dalam pengerjaan kerajinan bambu. Hal im sesuai dengan penelitian Kasmudjo et.al (2013), nilai berat jenis berpengaruh terhadap kualitas bahan bambu yaitu kemudahan dalam pemotongan, cacat, pengebora, pembubutan, pengetaman dan pengamplasan.

\section{Berat Jenis Kering Udara}

Nilai berat jenis kering udara bambu tali berkisar antara $0.62-0.75$ dengan nilai ratarata sebesar 0,68. Nilai berat jenis kering udara bambu tali dapat dilihat pada tabel dibawah ini.

Tabel 7. Nllai berat jenis kering udarae bambu tali berdasarkan arah aksial Table 7. specific gravity of air-dried tali bamboo based on the axial directions

\begin{tabular}{ccccc}
\hline Arah aksial & 1 & 2 & 3 & Rata-rata \\
\hline Pangkal & 0.63 & 0.62 & 0.66 & 0.64 \\
\hline Tengah & 0.68 & 0.68 & 0.64 & 0.67 \\
\hline
\end{tabular}



Ujung
0.73
0.75
0.74
0.74

Rata-rata

0.68

0.68

0.68

0.68

Berat jenis kering udara tertinggi terletak pada bagian ujung yaitu 0,74 dan berat jenis terendah terletak di bagian pangkal yaitu 0.64. Nilai berat jenis cenderung meningkat dari pangkal menuju ujung. Hal ini didukung oleh penelitian Wulandari F.T (2015), yang menyatakan nilai berat jenis kering udara cenderung meningkat dari pangkat menuju ujung.

Tabel 8. Analisis keragaman berat jenis kering udara bambu tali berdasarkan arah aksial Table 8. Anova of density of air-dried tali bamboo based on the axial directions

\begin{tabular}{llllll}
\hline Sumber Keragaman & Jumlah Kudrat & Df & $\begin{array}{l}\text { Kuadrat } \\
\text { rata-rata }\end{array}$ & $F_{\text {hit }}$ & Sig. \\
\hline Aksial & .017 & 2 & .008 & 23.844 & .001 \\
Error & .002 & 6 & .000 & & \\
Total & 4.194 & 9 & & & \\
\hline
\end{tabular}

Berdasarkan hasil analisis keragaman menunjukan bahwa pada arah aksial nilai signifikansi 0.011 , dimana nilai nilai tersebut lebih kecil dari taraf yang di berikan yaitu 0,05 sehingga $\mathrm{H}_{0}$ ditolak dan $\mathrm{H}_{1}$ diterima sehingga berat jenis kering udara bambu tali pada bagian ruas bambu tali pada arah aksial berbeda. Perbedaan ini terletak pada bagian pangkal dan bagian tengah batang berbeda dengan bagian ujung batang namun pada bagian tengah batang tidak berbeda dengan pada bagian pangkal. Hal ini sesuai dengan pernyataan Widjaja, E. A. (2001), yang menyatakan salah satu yang mempengaruhi berat jenis adalah posisi dalam batang, selain itu juga disebabkan oleh besarnya sel, tebal dinding sel dan hubungan sejumlah sel yang bermacam-macam. Dengan mengetahui nilai berat jenis memudahkan dalam pengerjaan kerajinan bambu. Hal im sesuai dengan penelitian Kasmudjo et.al (2013), nilai berat jenis berpengaruh terhadap kualitas bahan bambu yaitu kemudahan dalam pemotongan, cacat, pengebora, pembubutan, pengetaman dan pengamplasan.

\section{Berat Jenis Kering Tanur}

Nilai rata-rata berat jenis volume kering tanur dapat dilihat pada tabel dibawah ini. Berdasar tabel dibawah nilai rata-rata berat jenis kering tanur bambu tali sebesar 0,70.

Tabel 9. Nilai berat jenis tanur bambu tali berdasarkan arah aksial.

Table 9. Density of oven tali bamboo based on the axial directions

\begin{tabular}{ccccc}
\hline Arah aksial & 1 & 2 & 3 & Rata-rata \\
\hline Pangkal & 0.64 & 0.63 & 0.68 & 0.65 \\
Tengah & 0.70 & 0.71 & 0.66 & 0.69 \\
Ujung & 0.74 & 0.78 & 0.77 & 0.76 \\
\hline
\end{tabular}



Rata-rata
0.69
0.71
0.70
0.70

Nilai berat jenis kering tanur bambu tali berkisar antara $0.63-0.78$. Berat jenis kering tanur bambu tali tertinggi terletak pada bagian ujung sebesar 0,76 dan terendah terletak di bagian pangkal yaitu 0.65 . Nilai berat jenis kering tanur bagian ujung cenderung lebih tinggi dibandingkan bagian bagian pangkal karena kadar air pada bagian ujung batang bambu lebih rendah dibandingkan bagian pangkal (Purwito, 2012).

Tabel 10. Analisis keragaman berat jenis kering tanur bambu tali berdasarkan arah aksial Table 10. Anova of density of oven tali bamboo based on the axial directions

\begin{tabular}{llllll}
\hline Sumber Keragaman & Jumlah Kuadrat & Df & $\begin{array}{l}\text { Kuadrat } \\
\text { rata-rata }\end{array}$ & $F_{\text {hit }}$ & Sig. \\
\hline Aksial & .020 & 2 & .010 & 16.218 & .004 \\
Error & .004 & 6 & .001 & & \\
Total & 4.448 & 9 & & & \\
\hline
\end{tabular}

Berdasarkan hasil analisis keragaman menunjukan bahwa pada arah aksial nilai signifikansi 0.004 , dimana nilai nilai tersebut lebih kecil dari taraf yang di berikan yaitu 0,05 sehingga $\mathrm{H}_{0}$ ditolak dan $\mathrm{H}_{1}$ diterima sehingga berat jenis segar bambu tali pada bagian ruas bambu tali pada arah aksial berbeda. Perbedaan ini terletak pada bagian pangkal dan bagian tengah batang berbeda dengan bagian ujung batang namun pada bagian tengah batang tidak berbeda dengan pada bagian pangkal. Hal ini sesuai dengan pernyataan Widjaja, E. A. (2001), yang menyatakan salah satu yang mempengaruhi berat jenis adalah posisi dalam batang, selain itu juga disebabkan oleh besarnya sel, tebal dinding sel dan hubungan sejumlah sel yang bermacam-macam.

\section{KESIMPULAN}

Sifat fisika bambu tali : kadar air kayu segar (51\% $-119.82 \%)$, kadar kering udara $(13.03 \%-15.04 \%)$, berat jenis volume segar $(0.51-0.72)$, berat jenis volume kering udara (0.62 - 0.75), berat jenis volume kering tanur (0.63 - 0.78). Arah aksial tidak berpengaruh terhadap sifat fisika bambu tali kecuali pada pengujian kadar air segar, sehingga semua bagian dari batang bambu tali (pangkal, tengah dan ujung) dapat dimanfaatkan sebagai bahan baku bambu kerajinan.

\section{DAFTAR PUSTAKA}

Abdullah, AH.2014.Physical and mecanical properties of five Indonesian bamboos.Jurnal Earth and Environmantal science .60012014.

Basri dan Sarifudin. 2006. Sifat Kembang Susut dan Kadar air Keseimbangan Bambu Tali (Gigantocbloa apus Kurtz) Pada Berbagai Umur dan Tingkat Kekeringan. Jurnal Penelitian Hasil Hutan Vol 24 No.3.

Eskak, Edi.2016.Bambu ater (Gigantochloa atter) sebagai bahan substitusi kayu pada ukiran asmat. Jurnal dinamika kerajinan dan batik. Vol 33.No1. 
Hadjib, N.2006.Sifat Fisis Dan Mekanis Kayu Jati Super dan Jati Lokal Dari Beberapa Daerah Penanaman.Jurnal Penelitian Hasil Hutan.Vol 24.No 4.

Krisdianto, et.al, 2000. Sari Hasil Penelitian Bambu. Pusat Penelitian dan Pengembangan Hasil Hutan. Bogor.

Kasmudjo dan Sri Suryani, 2013. Prociding MAPEKI XVI. Diakses pada hari Kamis tanggal 14 Januari 2020 pukul 10.30 di website https://teknologihutan.fkt.ugm.ac.id/wpcontent/uploads/sites/675/2019/01/Pengaruh Perbedaan Jenis dan Bagian Batang Bam bu-1.pdf.

Pujirahayu, N.2012.Kajian Sifat Fisik Beberapa Jenis Bambu Di kecamatan Tonggauna Kabupaten Konawe.Jurnal. Fakultas pertanian.

Praptoyo, Harry.2012.Sifat Anatomi Bambu Ampel (Bambusa vulgaris Schrad).[Skripsi].Fakultas Kehutanan UGM

Praptoyo, Harry.2012. Sifat Anatomi Bambu Ampel (Bambusa Vulgaris Schrad) Pada Arah Aksial dan Radial. Jurnal.Fakultas Kehutanan UGM.

Purwito. 2012. Produk dari Bambu dan Turunannya. Dikutip dari :http//bamboo Indonesia wordpress.com/peneliti-bambu/purwito/makalah (diakses pada tanggal 3 November 2019).

Prawirihatmodjo. 2012. Sifat-sifat Fisika Kayu. Cakrawala Media. Yogyakarta.

Rini, D. (2018). SIFAT FISIKA BAMBU PETUNG (Dendrocalamus asper (Schult. f.) Backer ex Heyne) dari KHDTK (Kawasan Hutan Dengan Tujuan Khusus) SENARU BERDASARKAN POSISI AKSIAL. Jurnal Belantara, 1(2), 101-106. doi:https://doi.org/10.29303/jbl.v1i2.83

Rini, et al.2017.Studi Jenis Dan Persebaran Bambu Di kawasan Hutan Dengan Tujuan Khusus (KHDTK) Senaru. Jurnal Sangkareng Mataram. Volume 3 No 4.

Syahroni, M.2017. sifat fisika bambu tali (Gigantochloa apus kurs) dan Bambu Tutul (Bambusa valgaria Schrad). [Skripsi].Program studi kehutanan.UNRAM

Widjaja, E. A. 2001. Identikit Jenis-jenis Bambu di Kepulauan Sunda Kecil. Bogor: Herbarium Bogoriense, Balitbang Botani, Puslitbang Biologi-LIPI

Wulandari, T.2014. Sifat Fisika Empat Jenis Bambu Lokal Di Kabupaten Sumbawa Barat.Media bina ilmiah. Vol 8,No 7. Prodi kehutanan,UNRAM

Wulandari, 2018. Identifikasi Jenis Dan Sifat Fisika Bambu dikawasan Hkm Desa Aik Bual, laporan penelitian PNPB Jurusan Kehutanan Fakultas Pertanian Universitas Mataram. 